\title{
International Sport and Diplomacy's Public Dimension: Governments, Sporting Federations and the Global Audience
}

\author{
GEOFFREY ALLEN PIGMAN
}

Geoffrey Allen Pigman is Research Associate and Visiting Fellow, Department of Political Sciences, University of Pretoria, Visiting Research Fellow, Center for Global Change and Governance, Rutgers University-Newark, and Research Associate, Institute for Global Dialogue (Pretoria, South Africa). He is a graduate of Swarthmore College, The Johns Hopkins University School of Advanced International Studies, and received his D. Phil. from the University of Oxford. His principal areas of research are contemporary diplomacy, international trade politics, and foreign economic policymaking. His publications include The World Economic Forum: A Multistakeholder approach to global governance (2006), Contemporary Diplomacy (2010), and the forthcoming Diplomacy of International Trade and Commerce (2014). He is a founding member of the Diplomacy and International Sport research group.

\begin{abstract}
International sporting competition has played a rôle in diplomacy since at least the ancient Olympiad. Competitors in international sporting events have always possessed the capacity to represent their governments and peoples - and, more latterly, sponsoring firms - not only to foreign governments but also to foreign populations and the global public more broadly. The rapid increase in the number and variety of international sporting competitions over the past 50 years has seen "the increase in people-to-people exchanges, both virtual and personal, across national borders." The communicative power of international sport has increased dramatically by the information and communications technologies revolution over the past several decades, enabling the audience for major sporting events to expand to hundreds of million people. Yet, little study on how international sport relates to public diplomacy has occurred and remains not well understood. This analysis fills in this lacuna.
\end{abstract}

International sporting competition has played a rôle in diplomacy since at least the ancient Olympiad. The Olympic Truce, during which warring governments suspended conflict to enable competitors and spectators to travel to and attend the Olympic Games, consecrated the principle that sport is integral to diplomacy's mission of mediating estrangement and overcoming alienation between governments and between peoples. Competitors in international sporting events have always possessed the capacity to represent their governments and peoples (and, more latterly, sponsoring firms) not only to foreign governments but also to foreign populations and the global public more broadly. Spectators supporting different sides at live international sporting events are brought together, ideally at least, by a shared love of the game. The rapid increase in the number and variety of international sporting competitions over the past half century falls under what Snow describes as "the increase in people-to-people exchanges, both virtual and personal, across national borders." ${ }^{1}$ The communicative power of international sport has been amplified dramatically by the revolution in information and communications technologies over the past several decades, which has enabled the audience for major sporting events to expand from attendees of live competitions and hearers of word-of-mouth accounts to the over one third of the global population with access to (at least) audio broadcasting. ${ }^{2}$ This transformation has in effect 
made international sport a primary communication channel in a contemporary environment in which diplomacy increasingly involves communication with the global public. And yet how international sport relates to public diplomacy has been little studied and remains not well understood.

Whilst public diplomacy itself is anything but new, the revolution in information and communications technologies over the last several decades and the increased focus since the end of the Cold War on the importance to diplomacy of "soft power," the power to attract others to one's own views, has led to heightened scholarly and professional perceptions of the importance of diplomacy's public dimension. ${ }^{3}$ Some scholars embraced the notion that a "new" public diplomacy had emerged. This diplomacy highlighted the importance of non-state as well as governmental diplomatic actors, public diplomacy as relationship management, dialogic public diplomacy, the network structure of communication in public diplomacy, the ability of publics to check the veracity of public diplomacy messaging, and the rôle of public-to-public communications amongst others. ${ }^{4}$ However, the idea of a new public diplomacy to which Snow referred may have obscured to some degree a broader shift in the understanding of diplomacy itself and how the practice of diplomacy has evolved. In this "new diplomatic studies paradigm," a viable understanding of contemporary diplomacy must set aside older presuppositions about the nature of the actors and the system in which they operate: traditionally assumed separations between the domestic and the international, the public and private, the the political and the economic, the social and cultural. ${ }^{5}$ Public diplomacy of necessity occupies a much more central place in the toolbox of contemporary diplomatic instruments for representation and communication. As Hamilton and Langhorne observe, "audience participation seems set to become the norm in the theatre of global issues." ${ }^{\prime 6}$ Yet diplomatic representation and communication are anything but straightforward, and the rôle of the audience, the public, is more central and more complex than originally conceived by traditional diplomatic studies. The business of diplomacy rests on a perpetual underlying negotiation and renegotiation of who is entitled to diplomatic representation and who is entitled to represent whom. ${ }^{7}$ Similarly, Constantinou questions the assumption of classical diplomatic theory that a representative is empowered to act by sovereign authority. ${ }^{8}$ This identity politics of diplomatic accreditation, which often rests upon culture and economic power as much as it does upon power politics, in a globalized media age requires not only public interest but active public engagement and support if diplomacy is to achieve its objectives of mediating estrangement and overcoming alienation between actors. ${ }^{9}$

The diplomacy of international sport, and the public diplomacy that forms an integral component thereof, thus emerges as a quintessential case study demonstrating the part that public diplomacy plays in contemporary diplomacy as understood by a "new diplomatic studies paradigm." First and foremost, international sport would lose its essential meaning without an audience: international sporting competition matters only because people care about it and pay attention to it. Hence the act of competing in sport internationally is at its core about communicating to the public. The diplomacy of international sport involves a huge range of state and non-state actors: governments, national and global fans of sport (i.e. the global public) international sporting federations, global sponsor firms, global media firms, and multilateral organizations. Diplomatic communication must take place across the widest range of channels, extending from private exchanges between officials to meetings 
of international sporting federations to nation-branding campaigns aimed at securing country or city bids for major sporting events to global broadcasts of events and advertising. Sports-diplomacy renders problematic the relationships between sovereigns and representtatives in the most open and visible ways, as public claims and private negotiations over competing country names and flags to be used at the Olympics illustrate. ${ }^{10}$ Understand-ing supporters and sporting competition between sides and between polities more broadly is important to understanding how contemporary political and cultural identities are constructed and reconstructed. Likewise the business relationships negotiated to underpin and facilitate international sporting competition-sponsorship contracts, broadcast rights, development projects for new sporting facilities - are emblematic of the long-running public-private interplay in diplomacy. The objective of this paper is to explore and to analyze how public diplomacy and international sport are interrelated, and from this analysis to generate a normative perspective on how each could be used better in the service of the other.

A basic taxonomy devised to understand how international sport and diplomacy interact in the broad sense proves equally useful for understanding relationships between sport and public diplomacy. At the broadest level, one can distinguish between international sport used as a tool of diplomacy by governments, on the one hand, and international sport-asdiplomacy, the diplomacy that takes place between a range of different types of actors when international sporting competition is organized and hosted, on the other. ${ }^{11}$ The former category tends to be better known to scholars of diplomacy than the latter, but international sport is playing a significant part in public diplomacy in both categories, as the sections that follow elaborate. Using this taxonomy, this study seeks to map the rôle of sport in public diplomacy to raise questions about its effectiveness as a public diplomacy instrument, how that effectiveness can be measured, and to generate normative prescripttions for policy makers going forward.

The section that follows discusses how governments use sport as a tool of public diplomacy. Public diplomacy has become an essential component of the soft power resources employed by governments in an age that disfavours the effective use of hard power on its own. ${ }^{12}$ Hocking regards public diplomacy as a form of soft power, the power to attract. A state's culture can be attractive to outsiders even when its government is not. Snow concurs: "soft power is culture power." ${ }^{13}$ As Nye argues, much soft power originates in civil societyincluding sport-and not from governments. "Much of American soft power has been produced by Hollywood, Harvard, Microsoft, and Michael Jordan." ${ }^{14}$ International sport thus can serve as one of many public diplomacy instruments in a government's toolbox. Fisher contends that public diplomacy can be understood as falling within categories of cultural exchange, cultural diplomacy and broadcasting and, within each category, can be regarded as comprising a continuum of activities that extends from government-driven public diplomacy to privately-driven intercultural relations. ${ }^{15}$ International sport is important in all three categories and can be seen playing a part at every point along this public-private continuum. Though often not organized by governments, sport has a significant impact nonetheless.

When governments use sport as a tool for carrying out public diplomacy, it is often in the context of putting cultural diplomacy in the service of traditional, haute politique, security- 
related objectives. One of the most common objectives of this kind of diplomacy is to secure popular support for diplomatic engagements and relationships. When the governments of the United States and the People's Republic of China agreed that an American Ping-Pong team would tour China in 1971, one of the primary objectives of both governments was to use the tour to gauge how each country's population would react to the prospect of a thawing in and eventual normalization of relations between the two governments. As table tennis is a much more important sport in Chinese culture than it is in the USA, senior officials of the Chinese Communist Party could be certain of public interest in the tour. Yet U.S. foreign policy-makers in the administration of President Richard M. Nixon also gauged correctly that the competition narrative would appeal to the US public and capture their attention. The Ping-Pong tour received major media coverage in each country. Both governments' assessments of public reaction to the tour were very positive, which paved the way for U.S. Secretary of State Henry Kissinger's visit to China a few months later and President Nixon's ground breaking visit the following year. ${ }^{16}$

More troubled diplomatic relationships in which direct communications by governments may be viewed by foreign populations as suspect call for public diplomacy at a different point along Fisher's public-private continuum. Governments may choose to communicate to a foreign public indirectly as part of a strategy of seeking to influence that population's government. Sport is an important instrument in the PD toolbox for indirect communication. As Riordan argues, "[e]ngaging with foreign civil societies is often best done by the non-governmental agents of our own civil societies."17 After the Kashmir crisis of 2002 brought India and Pakistan to the brink of war, a series of cricket matches were facilitated by both governments in 2004 to reduce tensions and re-establish a level of public comfort needed to engage with the other on an ongoing basis. Both governments decided that it would be productive to "permit" a cricket tour as an initial step toward normalizing diplomatic relations, opening borders and engaging in direct negotiations. The logistics of the tour were left to the respective national cricket federations and to the media firms that broadcast the matches to the national publics. Members of the national sporting federations and the players on the national sides, cognizant of the diplomatic significance of the tour, were happy to play their part, even as they were aware of the limitations on what they could accomplish. Rameez Raja, the chief executive of the Pakistan Cricket Board, said "I'm absolutely delighted and thrilled that this thing is happening and that cricket has been given a great deal of importance in this set-up, because not only our cricketing relations will improve but also cricket has been made part of our bi-lateral talks, so from that point of view I am very, very happy." Likewise, an enthusiastic but serious Sourav Ganguly, India's captain, remarked "whenever we travel, we travel as ambassadors for the country." But Raja warned specifically that sportsmen should not become involved in the political process. "We cricketers come from a certain background and we should put politics on the back burner."18

Part of sport's utility to governments as a public diplomacy tool lies in a government's ability to sanction whether a particular competition takes place or not. In such situations a government decision not to play can also be seen as an effective message to the foreign public. When the England and Wales Cricket Board [ECB] decided that England's cricket side would not play a World Cup match scheduled to be played in Zimbabwe as part of the South Africahosted 2003 World Cup owing to concerns about player security, the UK government was 
faced with a difficult choice from a public diplomacy perspective. The International Cricket Council had decided that ECB security concerns were not valid reasons for refusing to play, meaning that failure to compete would result in forfeiture of the match to Zimbabwe. The UK government were aware that, irrespective of the merits of the security question, their position would be interpreted by the global public in the context of the troubled ZimbabweUK diplomatic relationship. By deciding to support the ECB's decision not to play the match, the Westminster government reaped gains with a broad swathe of the global public by appearing to take a principled stand against the tyranny and human rights violations of Zimbabwe's President Robert Mugabe, whilst risking alienating a minority but measurable segment of the global public who sympathise with Mugabe's anti-colonialist rhetoric. In this instance it was difficult for the UK to score a clean "win" in public diplomacy terms. This case is also an example of a particularly challenging task for the UK government of measureing the impact of their decision on public opinion in relevant countries, in this context Zimbabwe and South Africa in particular. ${ }^{19}$

By far the larger public diplomacy component of how international sport is used as a diplomatic tool by governments falls under the rubric of place branding and its concomitant promotion of investment, trade, and tourism. In recent decades, governments have devoted increasing resources to building, shaping, and managing the image of their nations in the minds of the global public. ${ }^{20}$ This project has drawn increasingly upon brand management strategies applied by successful global firms. ${ }^{21}$ Over the past century a number of governments have attempted with greater or lesser success to use sport specifically as an identifier in the minds of the global public for the kind of state and society that they were trying to build. Anholt's survey data show that hosting an Olympiad creates a particularly enduring association of the host city with the Olympics in the minds of the global public. Nearly 90 percent of the surveyed population associated Sydney with the Olympics following the 2000 Games, and public association of Paris with the 1924 Olympics persisted over three-quarters of a century later. Other major international sporting events showing measurable public association with the host country or city include the Tour de France and the New York Marathon. ${ }^{22}$ Anholt contends that major sporting events do not themselves brand their host locations but, rather, create an opportunity that the global media spotlight can provide for the hosts to brand themselves. ${ }^{23}$ This effort can be carried out with great success by constellations of host governments and private actors, as the 1992 Barcelona Olympiad and the 2010 Federation Internationale de Football Association [FIFA] World Cup in South Africa illustrate. Cornelissen argues that South Africa's government made its World Cup bid attractive by constructing a compelling pan-African identity that emphasized the importance of football in African societies and stressed that it was Africa's "turn" to host a major international sporting event. ${ }^{24}$ Deos chronicles how the New Zealand government successfully built networks with the New Zealand Rugby Union, business, and other non-state actors that contributed to the success of the 2011 Rugby World Cup in hosting visitors and in the process showcasing the country favourably as a destination for investment and tourism. ${ }^{25}$

However, when there is a disconnect between what the host presents and what the public sees, branding is likely to become problematic. Adolf Hitler's government in Germany sought to use the 1936 Berlin Olympiad as a showcase for the accomplishments and racist values of his National Socialist party, but in the event was embarrassed by the successes of 
non-"Aryan" competitors like the American sprinter and long jumper Jesse Owens, who won four gold medals. ${ }^{26}$ After the Second World War, the Soviet Union and its satellite states (particularly the German Democratic Republic) invested heavily in programmes to train international-standard competitors in many sports in order to be seen as dominant on the global stage that the Olympics rapidly came to provide. The opportunity for international Olympic visibility accelerated as television became ubiquitous in western industrialized countries. The Soviet government made it a mark of achievement, particularly in the eyes of the publics in its satellite states and across the developing world, to best the United States and other western competitors in Olympic medal totals. In various instances, however, these substantial sporting accomplishments were tarnished by subsequent revelations that competitors had used performance-enhancing substances that, if not banned already, were later proscribed. Numerous former competitors of the German Democratic Republic (East Germany) after the end of the Cold War admitted to having been given steroids as part of their official training programmes and have subsequently sought compensation for the ensuing medical disorders that steroid use has caused. One East German sprinter, Ines Geipel, requested that her 1984 record time be stricken owing to steroid use. $^{27}$

More recently, international sporting events have been viewed by many governments as an ideal venue to showcase a country, its cities, and people to the world as attractive destinations for tourism and investment. National governments routinely team with domestic sporting federations, local governments, and private sector interests (for instance, sponsoring firms) to bid for, finance, and co-ordinate the hosting of such events. "Megaevents" such as the Olympic Games, World Cups of major sports such as soccer, rugby, and cricket, major competitions of "tour" sports such as tennis (e.g. the Australian Open and Wimbledon), golf (e.g. the U.S. Masters), cycling (e.g. the Tour de France), and motor sports (e.g. Formula One's Malaysian Grand Prix) offer a range of channels for place branding, which is the communication of information about and images of a country with the objective of enhancing the country's familiarity and reputation in the minds of the global public. ${ }^{28}$ Thousands of spectators travel to mega-events to view the competition live, many of whom combine their spectator visit with additional tourism in country. Firms around the world in the travel, lodging, leisure, and tourism industries have the opportunity to bid on and participate in the construction and operation of the infrastructure required to host the competition. These firms can become key partners for governments in tourism promotion both during and after the sporting event. Global media coverage of the competition-print, television and radio, and internet-can serve as a continuous, extended, advertisement of the merits of the host country before audiences sometimes reaching over one-half of the world's population, provided that the hosting of the games is generally perceived as a success.

Two recent success stories in terms of place branding and promotion of investment and tourism have been the 2008 Beijing Olympiad and the 2010 Football (Soccer) World Cup in South Africa. The Chinese government spent $\$ 44$ billion, sparing no effort in producing an Olympic Games that showcased China as both a country at the leading edge of technology with the most sophisticated infrastructure and facilities and whose people are open, friendly, welcoming, and worldly. ${ }^{29}$ For months in advance, hired staff and volunteers were provided with language training and cultural coaching to prepare them to be good hosts to the thousands of international visitors who came to Beijing in August $2008 .{ }^{30}$ The creation of 
architecturally superb facilities such as the Bird's Nest stadium and the staging of complex, spectacular, and culturally rich spectacles at the opening and closing ceremonies within conveyed these images of and messages about China to a global audience in the billions. Even shutting down major industrial production in the Beijing region for two months was not a price too high to pay for having cleaner air during the Olympics (and creating a somewhat illusory impression of China's accomplishments in environmental manage-ment). ${ }^{31}$ Yet China's government was concerned about the potential for televised images of human rights protesters in Beijing demonstrating over contested issues such as Tibet in a way that could disrupt global perceptions of a well-run, orderly Olympiad. The Chinese government benefited in this regard when international attention was diverted by the Russian Federation's invasion of Georgia during the Beijing Olympics, an act criticized for violating the Olympic Truce (amongst other things).

Similarly, the South African government and their partners took on the challenge of showing to 2010 Football World Cup live spectators and the global media audience a nation that is developed economically, rich in opportunities for tourism and investment, and above all, safe for visitors. Prior to the World Cup, concerns existed that South Africa, the first African nation to hold a global sporting mega-event, would be pressed to provide adequate transport and lodging infrastructure for spectators and would be unable to guarantee the security of competitors and visitors in the context of high crime rates following the 1994 transition to majority rule. The government undertook a massive infrastructure programme, including new construction or major refurbishing of ten stadia around the country, major rebuilding and expansion of the country's motorway network, and construction of the initial leg of Africa's first high-speed rail system, the Gautrain, to connect O.R. Tambo International Airport to Sandton, the area of Johannesburg where most international visitors were expected to stay. To ensure effective security provision, the government assumed significant additional policing powers, including the creation of special courts to deal with violations during the Cup on an expedited basis, integrated the nation's military into the security infrastructure, put a huge number of additional law enforcement personnel onto the streets of cities hosting matches, and even resettled dwellers in informal settlements (shantytowns) adjacent to Cup venues to other locations. ${ }^{32}$

Smaller countries can also benefit, in proportional terms, from the place branding, investment, and tourism promotion gains to be had from hosting international sporting events. Regional competitions for major sports and international competitions in sports with smaller or niche followings can bring a significant number of visitors in keeping with the capacity of small and mid-sized venues and provide a measure of international media visibility. For the Cook Islands, a Pacific island state in free association with New Zealand and a total population of around 13,000 , tourism is the largest industry, bringing in approximately 100,000 visitors annually. Over the past decade the islands have undertaken several projects to construct competition facilities, including a 3000-seat national stadium for outdoor events and an indoor stadium. These investments paid off handsomely in securing significant international sporting competitions of appropriate scale and scope, including the quadrennial Pacific Mini Games, in which competitors from 22 Pacific nations compete in 15 sports, the world youth netball championships, in which 20 national teams from around the world were expected, and the Air New Zealand-sponsored Golden Oldies Rugby Mini Festival. Of perhaps even greater impact in building Cook Islands brand identity 
in the minds of international spectators, however, is Cook Islands competitors, both $\mathrm{Cl}$ residents and diaspora, in major international sporting competitions abroad. The Cook Islands won the "bowl" competition at the 2009 Wellington 7s, one of the major international rugby $7 \mathrm{~s}$ events, bringing to the Cook Islands visibility in a stadium venue of 34,500 and a global television audience of many millions. ${ }^{33}$

Another cultural channel through which governments use sport as part of their public diplomacy is the appointment and sending abroad of sports stars as "goodwill ambassadors." On these missions, competitors often meet with their counterparts in the sport in the receiving country, compete in exhibition matches, participate in teaching the sport to local youth, and engage in charitable events and activities related to the sport. Such tours, if successful, enhance the public image of the sport and the host country at the same time. The United States Department of State has sent Olympic gold medal winning figure skater Michelle Kwan and baseball star Cal Ripken, Jr., on overseas tours as "goodwill ambassadors" that have received very favourable publicity. Kwan has made several tours in her rôle, particularly to Asia, where her Asian-American family background has facilitated her capacity to mediate between U.S. and Asian cultures. ${ }^{34}$

On many occasions the same cultural mediation objective is achieved for a government's public diplomacy without a foreign ministry having to take the lead in organising a tour. U.S. tennis stars Venus and Serena Williams visited Nigeria and South Africa in November 2012 as part of a tour on behalf of the Breaking the Mould initiative, a charitable undertaking intended to inspire women of all ages to "break the mould" in whatever activity they choose. In South Africa, the Williams sisters played an exhibition match and gave local girls tennis instruction at the Arthur Ashe tennis centre in Soweto. ${ }^{35}$ Interviewed for the South African television magazine programme, Top Billing, Serena Williams commented, "we wanted to come to Africa to break that mould too and tell the young kids that you can do whatever you want to do, whether it be sports or anything else. ... "Venus Williams added, "for us to do what we do and to use sport to break the mould and help equality among all kinds of people is what we want to do." ${ }^{36}$ The Williams sisters brought a conscious message of empowerment to women and girls, reaching across gender, social, ethnic, and ability boundaries. In reference to their African heritage, they mediated multiple estrangements, all without being official diplomatic representatives of the United States government. Yet the U.S. Embassy in Pretoria worked co-operatively with the Williams tour, assisting in facilitating the visit and also promoting it on their social media sites to raise public awareness of the tour and its objectives.

In the section that follows, the relationship between international sport-as-diplomacy and public diplomacy is discussed. The Williams's South Africa visit also illustrates the point that international sport, when not being used by governments as a diplomatic instrument, still affects the public diplomacy of governments significantly, and in very different and often unanticipated ways. In addition, sport generates a huge amount of non-state actor public diplomacy by international sporting federations that arguably have a greater impact upon international relations than governments' use of sport in public diplomacy. Since its inception, international sporting competition has been organized primarily by civil society organizations, not by governments. National sporting federations host international events such as the tennis French Open at Stade Roland Garros. International sporting federations 
organize tour events across many countries, such as the FIS-International Ski Federation World Cup, or major events in single or multiple countries, such as the International Cricket Council Cricket World Cup finals, which took place in India, Bangladesh, and Sri Lanka in 2012. Privately funded and sponsored international sporting bodies host major international tour events like the Formula One motor racing tour. International sporting competition takes place with or without support from or engagement with governments. However, when international sporting events occur, diplomatic relations between nations are affected, hence the notion of "international sport-as-diplomacy." When sport-as-diplomacy takes place, governments' public diplomacy strategies and results are affected as well.

International sport-as-diplomacy has an impact upon public diplomacy in two significant ways. The first way can be viewed as the direct effects of international sporting competition upon diplomatic relationships between governments. These effects in turn influence how those governments conduct public diplomacy and what they accomplish with it. The second way is through the specialized diplomacy of international sport: the diplomacy that international sporting bodies such as the International Olympic Committee (IOC) and FIFA, as non-state diplomatic actors, must conduct to carry out their mission of organizing international sporting competition. ${ }^{37}$ Public diplomacy is a particularly large component of the diplomacy of international sporting bodies, as how effectively they communicate to global publics governs the level of public support that they receive for the sport and the events that they sponsor.

Several direct effects of international sport-as-diplomacy upon the public diplomacy of governments can be identified. One of the most important is when a domestic sporting league succeeds in becoming the league of choice for competitors from around the world at the highest level. The National Basketball Association (NBA) and Major League Baseball (MLB) in the United States, the (soccer/football) English Premier League (EPL) in the United Kingdom, the National Hockey League (NHL) in Canada and the United States (ice hockey), and more recently the Indian Premier League (IPL) in India (Twenty20 cricket) attract the best players worldwide in their respective sports to play for different teams in the league. Hence each season of the league, each game/match between any two teams in the league and each annual league championship serves as an international competition of note.

Leagues thus function as international networks that embody communication channels readily accessible to global publics (fans), governments and non-state actors (firms, CSOs) alike. For the nation in which the league resides, the league provides a major public diplomacy and place branding venue and along with it both opportunities and risks. On the positive side, global fans of the sport are attracted to the host country to watch games in which their home country players are competing. Millions of fans follow the league globally, giving each city's team a global in addition to a metropolitan and national fan base. This creates further opportunities for particularly famous sides like the EPL's Manchester United, Arsenal, and Chelsea to undertake tours of the Americas and Asia, further increasing their global visibility. ${ }^{38}$ The USA's National Football League recently has increased the number of matches its teams play in Europe each year from one to two to feed the demand of European fans for top level competition. Another variant of this format of international competition is "Champions League" tournaments, in which winning national clubs (each comprised of players from numerous countries) compete against each other. Examples 
include regional football/soccer tournaments such as the UEFA (Union of European Football Associations) Champions League and Europa League in Europe and the CONCACAF (Confederation of North, Central American, and Caribbean Association Football) Champions League in Central and North America, as well as the international Cricket Twenty20 Champions League (CLT20).

For their part, governments are not in a position to engineer the dominance of their nation's league in the global marketplace for a particular sport as part of their public diplomacy strategy, as leagues come to dominate owing to cultural and market-driven factors. Yet governments reap the benefits from the generally positive national image that the presence of a top sporting league engenders worldwide. A scandal, lengthy labour disputes, or other events that bring a league and its reputation into disrepute can bring with it a serious hit to the national brand, which governments are similarly limited in their capacity to act to remedy. Scandals in Italy's Serie A and Serie B football/soccer leagues in 2006 and 2011 devalued the reputation of Italian football across Europe, which may affect potential investors in tandem with Italy's ongoing reputation for political corruption, even as Italian tourism continues to benefit from a superior global brand (with the fifth highest tourism arrivals globally in 2010). ${ }^{39}$ Whenever player strikes in major sporting leagues in the USA threaten the cancellation of a significant portion of a league's competition season, public pressure mounts on the U.S. Congress to intervene in some way to resolve the dispute. This issue has arisen repeatedly with respect to Major League Baseball. Baseball strikes invariably precipitate public demands for Congress to repeal baseball's exemption from U.S. antitrust (competition) regulations, which currently prevents rival leagues to MLB from being started. ${ }^{40}$

Foreign players playing in top leagues abroad can bring global public diplomacy benefits to their country of origin as well as public diplomacy advantages to the country in which the league operates. Media interviews and "player of the match" award presentations always identify the country affiliation of players in top leagues, so the global audience makes the identification. When Chinese basketballer Yao Ming played for the NBA's Houston Rockets in the 2000s, he attracted a huge fan following in China, Houston, and around the United States, amongst the worldwide Chinese diaspora and amongst basketball fans everywhere. Attendance at NBA games, NBA television ratings, merchandise sales, and participation (players and spectators) in China's domestic basketball league all benefited from Yao Ming's presence. China is now the largest market for NBA merchandise outside of the United States. ${ }^{41}$ However, to achieve public diplomacy success for their home nations, their teams and their host leagues, players must be aware that intense media scrutiny means that their lives off the pitch/court/field are on view just as much as their competitive lives. This need not require a player to act entirely as diplomatic culture would expect of an upstanding representative. Celebrated Romanian tennis star llie "Nasty" Nastase was noted for his colourful personality, his mercurial temper and humorous antics on and off the court in the 1970s. Vanc argues that Nastase's unorthodox (and arguably undiplomatic) behaviour may have been regarded positively by the Romanian government of Nicolae Ceausescu, which despite being in the Soviet bloc wanted to craft a more independent image for Romania through sporting prowess. ${ }^{42}$ In a more notorious incident of off the pitch disreputable behaviour, talented Romanian footballer Adrian Mutu, who played for EPL side Chelsea was suspended in 2004 after testing positive for cocaine use and was linked by tabloid news- 
papers to purported sex-and-drugs sessions with prostitutes. ${ }^{43}$ The Mutu scandal did no favours to the reputations of either Romania or the EPL. The EPL at the time was already dealing with the high-living lifestyles of their players and their partners being lampooned by the globally popular TV soap opera Footballers' Wives, which ran from 2002 to 2006.

Governments can also suffer negative effects to their public diplomacy efforts when they are unable to meet basic requirements of international sporting bodies for planned competitions to take place, such as security, freedom from labour disputes, and threats to health and safety. This can lead to extensive negative media coverage of the event, the international sporting federation, and the host government. It can reduce the number of spectators who choose to attend the event and lower revenue from sponsors and advertisers. Byrne chronicles how problems of communication between Indian government ministries and the local Commonwealth Games Organizing Committee disrupted and delayed completion of competition facilities and accommodation for the 2010 New Delhi Commonwealth Games, which resulted in competing teams fearing for the games' safety and negative public perceptions of India. ${ }^{44}$ In another example, the management of Formula One took the decision to cancel the 2011 Bahrain Grand Prix in light of the political unrest in Bahrain during the Arab Spring uprisings. The decision came as a blow to the Bahrain government, which had been at pains to convince Formula One organizers that it could provide adequate security for teams and drivers. The annual Grand Prix is one of Bahrain's most high visibility place branding events. Continued public protests in Bahrain led the holding of the 2012 race to be cast into doubt as well, with government officials once again making great efforts to communicate to Formula One officials and the sport's global fan base that Bahrain is a safe and welcoming venue for the event. In the event, the 2012 competition took place without incident. ${ }^{45}$

The second major way that international sport-as-diplomacy affects more broadly public diplomacy is through the specialized diplomacy of international sport. The specialized diplomacy of international sport accords closely with Snow's observation that an increasing degree of public-to-public (P2P) diplomacy is taking place, in which the communications of governments, private, and non-state actors all engage global publics. ${ }^{46}$ Chehabi dubs this matrix of people-to-people diplomatic contacts "intersocietal relations." ${ }^{47}$ In order for major international sporting competitions to take place, it requires organizations to co-ordinate and manage them. In many cases, including the Olympics and many sports that hold World Cup format tournaments (soccer/football, cricket, rugby, basketball, etc.) the facilitating organization is an international sporting body constituted of representatives of national and, in some cases, regional sporting federations. These sporting bodies have emerged as some of the most high profile of non-state diplomatic actors on the global stage, and in no other diplomatic actors can public diplomacy be said to be more critical to their mission than these. $^{48}$

Producing an Olympiad or World Cup tournament requires international sporting bodies to conduct extensive diplomatic negotiation and communication with all of the stakeholders in an event: host country and city governments, global firms that sponsor the event, global media firms that broadcast it, and, in some cases, civil society organizations concerned with issues such as human rights and environmental protection. Moreover, international sporting bodies must communicate continually with all of the member national and regional sporting 
federations and, in some cases, with the individual competitors themselves. The IOC recognizes the diplomatic nature of its principal function:

Acting as a catalyst for collaboration between all parties of the Olympic family, from the National Olympic Committees (NOCs), the International Sports Federations (ISFs), the athletes, the Organising Committees for the Olympic Games (OCOGs) to the TOP partners [ed. - major sponsors], broadcast partners and the United Nations agencies, the International Olympic Committee (IOC) shepherds success through a wide range of programmes and projects. ${ }^{49}$

To achieve their objectives, international sporting bodies must be in the business of diplomacy on their own behalf: representation, communication, negotiation, promotion, all of the activities that diplomats of governments and of other non-state actors (e.g. the World Trade Organization, the United Nations, etc.) do. They must hire professionals skilled at these types of diplomatic tasks to do the specialized diplomacy of the organization full time.

One of the keys to success for international sporting bodies like the International Rugby Board and the Federation of International Lacrosse is that they must be perceived by all of their interlocutors, and by the global fan base to at least a considerable degree, as legitimate and competent. As Zaharna and Holmes both observe, in order to disseminate information credibly, organizations must be perceived as credible and trustworthy by the global public. ${ }^{50}$ Hence, like other international organizations, each international sporting body needs to undertake its own public diplomacy: to inform and engage in dialogue with the global public about its purpose and promote its objectives. ${ }^{51}$ All major sporting organizations have their own rich and informative websites, which often promote the organization in ambitious, if not to say grandiose, terms, linking the importance of sport with world peace, economic development, education, inclusiveness, and other lofty human values. The mission statement of the IOC in the Olympic Charter reads much like a global human rights charter. The first detailed objective in the IOC mission statement is: "to encourage and support the promotion of ethics in sport as well as education of youth through sport and to dedicate its efforts to ensuring that, in sport, the spirit of fair play prevails and violence is banned." ${ }^{152}$ Similarly, FIFA's short mission statement is "[d]evelop the game, touch the world, build a better future" or, as rendered in more specific terms: "[w]e see it as our mission to contribute towards building a better future for the world by using the power and popularity of football." ${ }^{53}$ These mission statements and so many others like them issued by international sporting bodies, if taken at face value, accord with Fitzpatrick's advocacy of a relationship management approach to public diplomacy, in which actors hold a worldview "characterized by symmetry and mutuality." This approach to public diplomacy favours dialogue and a sense of mutual interest rather than a strictly self-interested use of such diplomacy as a soft power tool to advance one's own policy agenda. ${ }^{54}$

Sporting bodies would appear to be better candidates than governments for embracing Fitzpatrick's symmetrical worldview and using public diplomacy to develop and advance a broad agenda of mutual global interests and values. Yet the difficulty that many international sporting bodies face from a public diplomacy perspective is that public perception of their actions regularly falls short of the image that they seek to project. Organizations like the IOC and FIFA have been beset by scandals in recent years that have 
called into question their adherence to principles of sound governance and transparency and, thus, more broadly to their credibility. Accusations of bribes being paid by bidders for the 2002 Winter Olympics and, more recently, the resignation of the Caribbean football federation president, Jack Warner, amidst accusations of direct attempts to influence the 2011 FIFA presidential election cast serious doubt upon the probity of the governance of international sporting bodies. ${ }^{55}$ For both the IOC and FIFA, the scandals set in motion processes of reform intended to increase operational transparency and enforce higher ethical standards that, in FIFA's case anyway, are far from complete. The challenge for the public diplomacy of international sporting bodies, as for governments and other institutions, is that reputational damage often takes much longer to repair than it does to occur. Yet sporting organizations are in the somewhat fortunate position that when next they produce another Olympiad or World Cup, if the event is a great success in the eyes of the global public, it can distract public attention from the ongoing impact of scandal at least to a certain degree.

The foregoing study suggests a few preliminary prescriptive guidelines that different types of diplomatic actors all might want to consider as they engage in public diplomacy relating to international sport going forward. The first is that the decision to use public diplomacy as a diplomatic instrument is in fact no longer a choice, either for governments or for non-state diplomatic actors. Exploration of the complex and developing relationship between international sport and public diplomacy serves to underscore the observation made by scholars of the new diplomatic studies paradigm that the global public has become a full participant in contemporary diplomacy, and that is not going to change in the future. The global public have growing expectations of how actors on the global diplomatic stage should behave: governments of states, multilateral organizations, international sporting federations, international media firms, global sponsor firms. These behavioural expectations include fairness, transparency, efficiency, incorruptibility, respect for human rights, and accountability to their constituents and stakeholders. Increasingly the global public are finding highly visible ways to articulate their expectations as demands and to hold actors accountable. The media play a key part in this process, in addition to being one of the actors being held accountable. As the news cycle has accelerated with the revolution in information and communications technologies, the need for actors to respond more rapidly has increased. Any riot or other misbehaviour by supporters at a football match inspired by nationalism or racism can be expected to become immediate fodder for the global media and its viewers, thus requiring nearly an immediate a response from the national and regional football federations, FIFA, and the governments of the nations involved. ${ }^{56}$ It also underscores the point that supporters of sporting sides, in addition to being part of the global public, are also stakeholders in, and thus a part of, the sides they support. Hence they too must bear responsibility for how they represent their club or side to the rest of the world in an age of instant global communication.

The second guideline is that, whilst assessment of the effectiveness of public diplomacy related to international sport as for all public diplomacy remains an enduring challenge, it is no less necessary for being so. As governments make decisions about how best to incorporate international sport into their public diplomacy strategies, they are likely to employ the same mechanisms to measure effectiveness that they commonly use to measure other public diplomacy instruments: polling and opinion surveys, blunter measures 
such as traffic over websites, etc. ${ }^{57}$ Academic studies, such as Lee's survey of the impact of the Beijing Olympics upon perceptions of China held by Hong Kong residents, produce analogous results. ${ }^{58}$ But whilst the impact of specific, discrete initiatives, such as an Indian cricket tour of Pakistan, on the target country's public perceptions measured through polling before and after the tour, the impact of ongoing public diplomacy strategies geared towards place branding and investment promotion is inherently more difficult to capture. The question of timeframe is also fundamental: the process for public perceptions of a nation, firm, or another actor to shift and remain changed often takes longer than simple polling can measure to demonstrate a causal link between a public diplomacy strategy and a desired outcome.

Holmes argues that governments can learn from private businesses that are better than governments at gathering and responding to feedback, the core of dialogic public diplomacy:

[B] usiness understands that there is no one "truth." They set out a stall, talk to consumers and get feedback. If the feedback is bad, you change the product. That is business. So broadening the task to gathering information and intelligent feedback allows business to play an active rôle in public diplomacy. Real dialogue, active engagement and questions of perception are the lifeblood of business. ${ }^{59}$

Firms tend to call their public diplomacy function "corporate communications" and have their own metrics for measuring its effect upon public perceptions of the firm (stock price movements, sales volumes, advertising revenue, media ratings, etc.). International sporting federations seeking to use public diplomacy most effectively in pursuit of their missions tend to fall somewhere in between governments and firms in how they measure and assess the effectiveness of public diplomacy strategies effectively. The record thus far shows that they have much to learn from both. As noted above, there can be a huge disconnect between what international sporting federations communicate to the public (and how they say it) and what the public hears. As noted at the outset, the lifeblood of international sport and its capacity to mediate in a diplomatic sense is public interest, attention, and support. Media ratings for sporting events can be an important indicator of this process but are also a crude measure in many respects. Ratings cannot distinguish between voyeurs of scandal and supporter admiration. Sales of branded merchandise may be a better marker. Fans are far more likely to purchase a jersey bearing the name and number of a player respected both on and off the pitch over his or her career, such as Brazilian soccer star Pele than that of a talented but scandal-tinged player such as Mutu. It can be difficult to disaggregate the effect of a particular sport-related public diplomacy initiative or a particular scandal on ongoing public perceptions of a government or international sporting body. A hugely successful 2014 football/soccer World Cup in Brazil may neutralize negative public perceptions of FIFA resulting from the 2011 scandal. The impact of any given public diplomacy event or negative data point may be marginal at most. One of the objectives of researchers going forward should be to collate best practices for measuring and assessing sport-related public diplomacy and to use that information to generate normative recommendations for both government strategies and reforms to international sporting bodies. The relationship between international sport and public diplomacy is still in its infancy, so the opportunities for each to serve the other better remain vast. 
The critical importance of assessing the effectiveness of public diplomacy, learning from and responding to failures, brings out a final, underlying guideline, which is that diplomacy in general and public diplomacy in particular is a reflexive practice. Thinking about how one engages in diplomatic representation and communication changes how one does it and in the process opens possibilities for making choices about doing it differently and, ideally, better. By creating a new independent ethics committee with powers to investigate the Executive Committee, FIFA has taken the significant step of recognizing the serious negative public image that its scandal-plagued World Cup bidding process has created in recent years. ${ }^{60}$ Time will tell whether the work of the ethics committee will have an impact on public perceptions of FIFA.

At a more personal level, individuals too must make choices about how to represent and communicate as diplomats in sport. The "Rainbow Laces" campaign, a project backed by British lesbian, gay, bisexual and transgender (LGBT) rights CSO Stonewall and the bookmaking firm Paddy Power, sought to draw attention to homophobia in football and sport more generally by urging players to wear rainbow-coloured laces in their football boots for one weekend in September 2013. Footballer Joey Barton, who plays for EPL side Queen's Park Rangers, publicized his support for the Rainbow Laces campaign widely, using his own stature and media presence to urge fellow competitors to support the cause. ${ }^{61}$ New Zealand speed skater Blake Skjellerup, one of the few openly gay competitors in the Olympic Games, made the decision to compete "out" prior to the recent controversy surrounding Russia's passage of homophobic legislation in the run-up to the February 2014 Winter Olympiad in Sochi, Russia. Skjellerup recently reflected on the importance of how the public perceive competitors as representatives in sport and on how that influenced his own choice to represent not only his country, but also the transnational LGBT community:

In 2014 I will be a short track speed skater from New Zealand, who has worked 4 years to be the best that he can be. Insignificantly I happen to be gay, and I like to think that I will not only be representing myself and my country, but also the wider LGBT community, who have fought so hard for where we stand today. ${ }^{62}$

Skjellerup decided that representing the LGBT community publicly (as well as New Zealand) as a competitor would make a positive contribution to international sport's message of inclusion to the global public and counter perceptions of homophobia in sport. International sport today is a uniquely well-suited global platform for diplomatic representation of and communication between global publics, but positive outcomes of this form of interaction are neither assured nor even favoured. It requires active engagement, reflection, and learning by each actor if the potential for public diplomacy in international sport is to realize its potential.

\section{Notes}

${ }^{1}$. Nancy Snow, "Rethinking Public Diplomacy," in Nancy Snow and Philip M. Taylor, eds., Routledge Handbook of Public Diplomacy (Abingdon, 2009), 6.

2. Richard Langhorne, The Coming of Globalization; Its Evolution and Contemporary Consequences (Basingstoke, 2001), 2-11. 
3. Joseph S. Nye, Jr., Soft Power; The Means to Success in World Politics (New York, 2004); Paul Sharp, "Dumb Public Diplomacy," in idem., Diplomatic Theory of International Relations (Cambridge, 2009), $266-92$.

4. Jan Melissen, "The New Public Diplomacy: Between Theory and Practice," in Jan Melissen, ed., The New Public Diplomacy; Soft Power in International Relations (Basingstoke, 2005), 3-27; Brian Hocking, "Rethinking the New Public Diplomacy," in Ibid., 28-43; Eytan Gilboa, "Public Diplomacy: The Missing Component in Israel's Foreign Policy," Israel Affairs, 12/4 (2006), 715-47; Kathy R. Fitzpatrick, "Advancing the New Public Diplomacy: A Public Relations Perspective," Hague Journal of Diplomacy, 2 (2007), 187-211; Shaun Riordan, "Dialoguebased Public Diplomacy: A New Foreign Policy Paradigm?," in Melissen, Public Diplomacy, 180-95.

5. Keith Hamilton and Richard Langhorne, The Practice of Diplomacy; Its evolution, theory and administration, 2nd edition (Abingdon, 2011), 259-71; Donna Lee and David Hudson, "The old and new significance of political economy in diplomacy," Review of International Studies, 30/3 (2004), 343-60; Geoffrey Allen Pigman and Brendan Vickers, "Old Habits Die Hard? Diplomacy at the World Trade Organisation and the 'New Diplomatic Studies Paradigm,'” International Journal of Diplomacy and Economy, 1/1 (2012), 19-41.

6. Hamilton and Langhorne, Practice of Diplomacy, 271.

7. Sharp, "Dumb Public Diplomacy."

8. Costas Constantinou, On the Way to Diplomacy (Minneapolis, MN, 1996).

9. James Der Derian, On Diplomacy (Oxford, 1987); Sharp, “Dumb Public Diplomacy."

10. David Lague, "Taiwan and China Squabble Over Olympic Torch," New York Times (17 September 2007): http://www.nytimes.com/2007/09/17/world/asia/17iht-taiwan.1.7533414. html?_r=0.

11. Stuart Murray and Geoffrey Allen Pigman, “'It's Our Game': Mapping The Hectic Convergence of Diplomacy and International Sport," Paper presented to the International Studies Association Annual Conference, San Diego, California, 1-4 April 2012; idem., "Mapping the Relationship Between International Sport and Diplomacy," Sport in Society, (November 2013): http://www.tandfonline.com/doi/abs/10.1080/17430437.2013.856616\#. UpJpCOKYwmA

12. Melissen, “New Public Diplomacy," 4.

13. Hocking, "Rethinking," 35. The quotation is from Snow, "Rethinking Public Diplomacy," 3.

14. Nye, Soft Power, 17.

15. Ali Fisher, "Four Seasons in One Day: The Crowded House of Public Diplomacy in the UK," in Melissen, New Public Diplomacy, 251-61.

16. H.E. Chehabi, "Sport Diplomacy Between the United States and Iran," Diplomacy and Statecraft, 12/1 (2001), 89-106; Zhang Qingmin, "The Chinese Case of Sport Diplomacy," Hague Journal of Diplomacy (forthcoming 2013); Rune-Wen Huang, "Diplomacy in the sports arena," 7 February 2008: http://uschina.usc.edu/fulllist@usct?author Rune-Wen\%20Huang 71.aspx.

17. Riordan, “Dialogue-based Public Diplomacy,” 191.

18. "India win Thriller," BBC News (13 March 2004):

http://news.bbc.co.uk/sport1/hi/ cricket/other_international/3507532.stm.

19. “England Game Called Off," Ibid. (12 February 2003):

http://news.bbc.co.uk/sport3 /cwc2003/hi/newsid_2740000/newsid_2749800/2749831.stm; “South Africa 
Threaten England Boycott," Ibid, (10 February 2003),

\{http://news.bbc.co.uk/sport3/cwc2003/hi/ newsid_2740000/newsid_2744100/2744151.stm.

20. Hocking, “Rethinking," 31; Melissen, “New Public Diplomacy," 19-21.

${ }^{21}$. Wally Olins, "Making a National Brand” in Melissen, New Public Diplomacy, 169-79.

22. Simon Anholt, Competitive Identity: The New Brand Management for Nations, Cities and Regions (Basingstoke, 2007), 108-10.

23. Ibid, 110 .

24. Scarlett Cornelissen, "Scripting the Nation: Sport, Mega-events, Foreign Policy and State-building in Postapartheid South Africa," Sport in Society, 11/4 (2008), 481-93.

25. Anthony Deos, "Sport and Relational Public Diplomacy: the Case of New Zealand and Rugby World Cup 2011," Sport in Society (November 2013) http://www.tandfonline.com/doi/abs/10.1080/17430437.2013.856588\#.UpJoleKYwmA.

26. Allan Hall, "Did Hitler shake hands with black 1936 Olympic Hero Jesse Owens?," Mail Online (11 August 2009): http://www.dailymail.co.uk/news/article-1205572/Hitler-shook-hands-black-1936-Olympic-hero-JesseOwens.html.

27. Luke Harding, "Forgotten Victims of East German Doping Take Their Battle to Court," Guardian (31 October 2005): http://www.guardian.co.uk/sport/2005/nov/01 /athletics.gdnsport3.

28. Simon Anholt, "Editor's Foreword to the First Issue," Place Branding, 1/1 (2004), 4-11; Annisa Lai Lee, "Did the Olympics Help the Nation Branding of China? Comparing Public Perception of China with the Olympics Before and After the 2008 Beijing Olympics in Hong Kong," Place Branding and Public Diplomacy, 6/3(2010), 207-27.

29. Lee, "Did the Olympics Help."

30. Wang Lidi and Zhang Jie, "Interpreting for Beijing Olympics," Graduate School of Translation and Interpretation, Beijing Foreign Studies University, undated, \{www.uni-graz.at/uedo1www-file-paperzhang.pdf\}, accessed 14 Nov. 2012.

31. "Beijing shuts down in attempt to cut pollution before Games," ESPN (19 July 2008): sports.espn.go.com/oly/news/story?id=3496825.

32. Cornelissen, "Scripting the Nation," 481-93; idem., "Mega Event Securitisation in a Third World Setting: Global Processes and Ramifications during the 2010 FIFA World Cup," Urban Studies, 48/15 (2011), 3221-40.

33. Geoffrey Allen Pigman, "Public Diplomacy, Place Branding and Investment Promotion in Ambiguous Sovereignty Situations: The Cook Islands as a Best Practice Case," Place Branding and Public Diplomacy, 8/1 (2012), 17-29.

34. United States Department of State, "Michelle Kwan to visit South Korea," Press Release 31 (December 2009): http://www.state.gov/r/pa/prs/ps/2009/dec/134591.htm.

35. “Williams Sisters Visit SA," Sport24 (2012): http://www.sport24.co.za/Multimedia/Tennis/Williams-sistersvisit-SA-20121105. 
36. "Venus and Serena Williams in SA," Top Billing, SABC (14 November 2012):

http://www.topbilling.com/articles/Venus-\&-Serena-Williams-in-SA.html?articlelD=1501.

37. Murray and Pigman, "Mapping the Relationship."

38. J. Simon Rofe, "It's a Squad Game: Manchester United as a Diplomatic Non-state Actor in International Affairs," Sport in Society (2014): http://dx.doi.org/10.1080/17430437.2013.856610.

39. World Bank, Data, International tourism, number of arrivals: http://data.worldbank. org/indicator/ST.INT.ARVL.

40. Nathaniel Grow, "Reevaluating the Curt Flood Act of 1998," Nebraska Law Review, 87 (2008), 747-58.

41. Ben Klayman, "NBA pushes China Expansion with New League Store," Reuters (12 May 2010): http://www.reuters.com/article/2010/05/13/us-nba-china-idUSTRE64C04320100513.

42. Antoaneta M. Vanc, "The Counter-intuitive Value of Celebrity Athletes as Antidiplomats in Public Diplomacy: Ilie Nastase from Romania and the World of Tennis," Sport in Society (November 2013):

http://www.tandfonline.com/doi/abs/10.1080/17430437.2013.856591?journalCode=fcss20\#.UpJpCOKYwmA

43. “Adrian Mutu Handed Nine-month Ban for Drug Use," Guardian (19 April 2010): www.guardian.co.uk/football/2010/apr/19/adrian-mutu-drug-ban.

44. Caitlin Byrne, "Relationship of Convenience?: The Diplomatic Interplay Between the Commonwealth Games Federation and the Commonwealth Games Host City," Sport in Society (November 2013): http://www.tandfonline.com/doi/abs/10.1080/17430437.

45. "Bahrain Stages F1 Grand Prix Despite Protests," BBC News (22 April 2012):

http://www.bbc.co.uk/news/world-middle-east-17803310.

46. Snow, "Rethinking Public Diplomacy," 6.

47. Chehabi, "Sport Diplomacy."

48. Murray and Pigman, "Mapping the Relationship."

49. IOC Mission Statement, "The Organization, Mission," Olympic.org: http://www.olympic.org/about-iocinstitution.

50. R.S. Zaharna, "Mapping out a Spectrum of Public Diplomacy Initiatives," in Snow and Taylor, Public Diplomacy, 89; Alison Holmes, "The Shifting Subtleties of "Special": Differences in US and UK Approaches to Public Diplomacy in Business," Journal of Business Strategy, 27/3 (2006), 22-29.

51. Melissen, “New Public Diplomacy," 14.

52. IOC Mission Statement.

53. Fédération Internationale de Football Association [FIFA], The Organisation, Mission \& Statutes: www.fifa.com/aboutfifa/organisation/mission.html.

54. Fitzpatrick, "Advancing." 
55. Alan Tomlinson, "The Supreme Leader Sails On: FIFA, Ethics and Leadership in the New Public Diplomacy," Sport in Society (2014): http://dx.doi.org/10.1080/17430437.2013.856590; John Sugden and Alan Tomlinson, FIFA and the Contest for World Football: Who Rules the Peoples' Game (Cambridge, 1998).

56. “England and Serbia Charged by UEFA Over Racism Row," BBC (17 October 2012):

http://www.bbc.co.uk/sport/0/football/19976781.

57. Pierre C. Pahlavi, "Evaluating Public Diplomacy Programmes," Hague Journal of Diplomacy, 2/3(2007), 25581.

58. Lee, "Did the Olympics Help."

59. Holmes, "The Shifting Subtleties of 'Special,'” 28.

60. “FIFA New Ethics Committee Will Examine 2018 and 2022 World Cup Awards," MercoPress/South Atlantic News Agency (28 August 2012): http://en.mercopress.com/ 2012/08/28/fifa-new-ethics-committee-willexamine-2018-and-2022-world-cup-awards.

61. Joey Barton, “Joey Barton: 'Why I Laced Up,'” Guardian (17 October 2013):

http://www.theguardian.com/voluntary-sector-network/2013/oct/17/joey-barton-why-i-laced-up; "Top Players Urged to Wear Rainbow Laces in Anti-homophobia Campaign," Guardian (16 September 2013): http://www.theguardian.com/football/2013/sep/16/players-rainbow-laces-anti-homophobia.

62. Blake Skjellerup, "Playing Out-Sport's Ability to Bring about Change," Sport in Society (2014): http://dx.doi.org/10.1080/17430437.2013.856610. 